\title{
Recovery of the human immunodeficiency virus from fibreoptic bronchoscopes
}

\author{
P J V Hanson, D Gor, J R Clarke, M V Chadwick, B Gazzard, D J Jeffries, H Gaya, \\ J V Collins
}

\begin{abstract}
Ten bronchoscopes that had been used on patients with the acquired immunodeficiency syndrome were sampled to determine the nature and extent of microbial contamination. Samples were taken by irrigating the suction biopsy channel with modified viral transport medium and by swabbing the insertion tube. Sampling was repeated after they had been cleaned in detergent and after two minutes' disinfection in $2 \%$ alkaline glutaraldehyde. Before being cleaned the seven bronchoscopes tested by polymerase chain reaction were contaminated with the human immunodeficiency virus, though infectivity and antigen assays gave negative results. Other organisms identified were hepatitis $B$ virus (1), commensal bacteria (9), and Pneumocystis carinii (4). Mean bacterial contamination was 2.27 log colony forming organisms per millilitre. Cleaning the bronchoscope before disinfection removed all detectable contaminants with a reduction in bacterial growth of up to $8 \log$ colony forming units $/ \mathrm{ml}$.
\end{abstract}

The emergence of human immunodeficiency virus infection has been accompanied by a changing pattern of pulmonary infection and new indications for performing fibreoptic bronchoscopy. Concern has been expressed about the possible transmission of HIV and other serious pathogens at bronchoscopy, a risk faced both by patients and by the staff of bronchoscopy units. Although one large retrospective study found a low incidence of infective complications of bronchoscopy, ${ }^{1}$ there have been reports of bronchoscopic cross infection with Mycobacterium tuberculosis, ${ }^{23} M$ chelonei, ${ }^{4}$ Serratia marcescens, ${ }^{5}$ and Pseudomonas aeruginosa. ${ }^{64}$ In addition, contamination of diagnostic samples with Bacillus species, ${ }^{7}$ Proteus, ${ }^{8}$ Pseudomonas aeruginosa, ${ }^{9}$ and $M$ avium-intracellulare ${ }^{10}$ has been reported. The reasons cited for persistent contamination tend to be inadequate precleaning, use of an ineffective disinfectant, and undetected damage to the internal surfaces of the bronchoscope.

Viral transmission at bronchoscopy has not been reported, though cross infection with hepatitis B virus occurred as a result of a contaminated gastroscope. ${ }^{11}$ Furthermore, injudicious use of a needle to remove tissue infected with HIV and hepatitis B virus from bronchoscope biopsy forceps has caused inoculation and infection with hepatitis B virus, though HIV was not transmitted (P Hopewell, personal communication). It is uncertain whether HIV contaminates bronchoscopes, and if so whether bronchoscopic inoculation might result in infection. The cleaning and disinfection procedures required for bronchoscopes used in patients with HIV infection have yet to be shown to be effective.

We sampled 10 bronchoscopes used on patients with the acquired immunodeficiency syndrome to identify and quantify as wide a range of contaminating microorganisms as possible. The reductions in contamination achieved with both cleaning and disinfection were measured. This small series is illustrative only: it would be necessary to sample 400 bronchoscopes to be $95 \%$ certain that effective decontamination was $99 \%$ reproducible.

\section{Methods}

SAMPLING

Ten Olympus BF10 bronchoscopes were sampled immediately after being used for diagnostic bronchoscopy on patients with pulmonary manifestations of AIDS. The suction biopsy channel was irrigated with antibiotic free viral culture medium (Eagles MEM, Gibco Ltd, Paisley, with $2 \%$ fetal calf serum and $0.24 \%$ sodium bicarbonate) and $3 \mathrm{ml}$ was collected at the distal end. The surface of the insertion tube was swabbed and the swab immersed in viral medium. Samples for viral analysis were treated with $100 \mu \mathrm{g} / \mathrm{ml}$ amphotericin B to prevent fungal overgrowth of tissue cultures. The bronchoscope was then washed in a Keymed autodisinfector in $0.5 \%$ neutral detergent (Applied Chemicals Ltd). Residual detergent was eluted with viral medium and sampling was repeated. The bronchoscope was disinfected in the autodisinfector with freshly activated $2 \%$ alkaline glutaraldehyde (Cidex, Surgikos) for two minutes and rinsed in tap water, and further samples were taken.

\section{HIV STUDIES}

Three methods were used for the detection of HIV. (1) Samples were stored at $-70^{\circ} \mathrm{C}$ and subsequently tested by the enzyme linked immunosorbent assay (ELISA) for core antigens (Abbott Diagnostic Products); (2) 1 $\mathrm{ml}$ aliquots were inoculated into fresh cultures of $10^{5} \mathrm{C} 8166 \mathrm{~T}$ lymphocytes (kindly provided by RC Gallo) in $3 \mathrm{ml} \mathrm{RPMI} 1640$ medium with 
$20 \mathrm{nU}$ anti- $\alpha$-interferon (Wellcome Diagnostics, Dartford), $20 \mu \mathrm{g} / \mathrm{ml}$ interleukin II, $10 \%$ fetal calf serum, and $1 \%$ penicillin, streptomycin and L-glutamine. Cultures were incubated at $37^{\circ} \mathrm{C}$ in $5 \%$ carbon dioxide for 28 days and examined for cytopathic changes. Culture fluid was harvested about every seven days for determination of p24 antigen by ELISA. (3) DNA was extracted from $100 \mu$ of each sample by the sodium dodecyl sulphate proteinase $\mathrm{K}$ technique. Amplification of HIV specific complementary DNA (cDNA) was performed by using the polymerase chain reaction described by Saiki et al. ${ }^{12}$ The method was modified to give 35 cycles of denaturation (one minute at $94^{\circ} \mathrm{C}$ ), annealing (one minute at $55^{\circ} \mathrm{C}$ ), and extension (one minute at $72^{\circ} \mathrm{C}$ ) in the presence of $200 \mu \mathrm{M}$ each of deoxyadenosine triphosphate, deoxycytosine triphosphate, deoxyguanosine triphosphate, and deoxythymidine triphosphate (Sigma Chemicals, Poole), with 17 base oligonucleotide primers from the p24 gag region of HTLV111 (Oswell DNA Service, Edinburgh) and 2.5 units of Taq polymerase in ionic buffer (Perkin Elmer Cetus, Norwalk, Connecticut). HTLV 1 transformed C8166 lymphocytes were used as a negative control. After amplification samples were analysed by electrophoresis on polyacrylamide gel and visualised with ethidium bromide. Southern blotting was carried out under high stringency conditions with $\mathrm{a}^{32} \mathrm{P}$ labelled cDNA probe derived from HTLV111B.

\section{MICROBIOLOGICAL ANALYSIS}

Samples were inoculated, diluted and undiluted, on to buffered charcoal yeast extract (for Legionella pneumophila), McConkey's and chocolate agar, aerobic and anaerobic blood agar, Sabaraud's medium at room and body temperature, and Lowenstein-Jensen slopes. Samples were also inoculated into Bactec radiometric medium for culture of mycobacteria. Indirect immunofluorescence tests for Pneumocystis carinii cysts (Northumbria Biologicals Ltd) and Grocott staining were performed. Bacterial and fungal cultures were read after two to five days' incubation and organisms quantified in colony forming units $(\mathrm{cfu}) / \mathrm{ml}$. Mycobacterial cultures were read after six weeks' incubation.

Identification and quantification of bacteria and Pneumocystis carinii cysts on 10 bronchoscopes used for patients with AIDS

\begin{tabular}{lllll}
\hline & & \multicolumn{2}{l}{ No of bronchoscopes contaminated } \\
\cline { 3 - 5 } Organism & $\log c f u / m l^{\star}$ & Dirty & Cleaned & Disinfected $\dagger$ \\
\hline Streptococcus viridans & $3 \cdot 64(1 \cdot 0-8 \cdot 0)$ & 8 & 0 & 0 \\
Streptococcus epidermidis & $2 \cdot 07(1 \cdot 7-2 \cdot 6)$ & 4 & 0 & 0 \\
Pneumocystis carinii & $1 \cdot 18(1 \cdot 0-1 \cdot 3)$ & 4 & 0 & 0 \\
Neisseria spp & $3 \cdot 53(2 \cdot 9-6 \cdot 0)$ & 2 & 0 & 0 \\
Staphylococcus aureus & $4 \cdot 34(2 \cdot 7-6 \cdot 0)$ & 1 & 0 & 0 \\
Coliform bacteria & $3 \cdot 00(-)$ & 1 & 0 & 0 \\
HBsAg & & 1 & 0 & 0 \\
HIV & & $7 / 7$ & $0 / 7$ & $0 / 7$ \\
\hline
\end{tabular}

$\star$ Except for $P$ carinii, where the units are cysts $/ \mathrm{ml}$.

†For two minutes in alkaline glutaraldehyde.

$\mathrm{HbsAg}$ - hepatitis B virus surface antigen.
OTHER VIRAL STUDIES

Viral cultures were performed in monkey kidney cells, human embryo fibroblasts, and Vero and HEp 2 cells for cytomegalovirus, respiratory syncytial virus, adenoviruses, enteroviruses, herpes simplex virus, and myxoviruses. Immunofluorescence tests were performed on cytomegalovirus and adenovirus cultures and haemadsorption for myxoviruses. The enzyme linked immunosorbent assay (Wellcozyme, Wellcome Diagnostics, Dartford) was performed for hepatitis B virus surface antigen.

\section{Results}

The microorganisms identified are given in the table. Of the 20 areas sampled on 10 bronchoscopes, 18 were found to be contaminated immediately after use of the bronchoscope. The mean contamination of the biopsy channel was 2.3 and of the tube surface $2 \log _{10} \mathrm{cfu} / \mathrm{ml}$. Contamination of $6 \mathrm{log} \mathrm{cfu} / \mathrm{ml}$ or greater occurred on three bronchoscopes. HIV cDNA was detected on all seven bronchoscopes examined, though tissue culture infectivity assays and antigen immunoassays gave negative results. After the bronchoscopes had been washed in neutral detergent all sites were free of all detectable microorganisms and HIV could no longer be detected even by the polymerase chain reaction. Samples taken after subsequent disinfection for two minutes in $2 \%$ alkaline glutaraldehyde were also free of contamination.

\section{Discussion}

The bacteria identified on the 10 bronchoscopes were predominantly commensal bacteria of the respiratory tract. The extent of contamination was considerably less than has been reported in studies of gastrointestinal endoscopes, perhaps owing to the fact that the respiratory tract is more sterile than the upper digestive tract but also in part to the fact that the gastroscope has longer, narrower channels than the bronchoscope. ${ }^{1314}$ Several organisms known to infect the respiratory tract in AIDS, such as mycobacteria and cytomegalovirus, were not found in this study, though they might have been found in a larger series.

The polymerase chain reaction was not available for testing samples from three bronchoscopes but it detected HIV genetic material on the other seven bronchoscopes. The site of contamination was the biopsy channel in three, the insertion tube surface in three, and both sites in one. The polymerase chain reaction amplifies specificDNA sequences by a factor of at least $10^{6}$ and, with Southern blotting for confirmation, can detect a specific DNA sequence in a single cell against a background of $10^{5}$ uninfected cells. ${ }^{12}$ Laboratory contamination, a potential source of false positive results, ${ }^{15}$ is unlikely to have produced the pattern of positive results seen in this study as the samples were extracted under identical conditions and tested in random order. The origin of the infected cells is uncertain: HIV 
has been isolated from alveolar macrophages, ${ }^{16}$ bronchoalveolar lavage fluid, ${ }^{17}$ and open lung biopsy tissue ${ }^{18}$ as well as blood and saliva.

Samples shown to be positive by the polymerase chain reaction did not infect tissue cultures, suggesting that the virus was present in non-infectious form or in amounts too small to be detected by tissue culture. HIV antigens could not be found on bronchoscopes with the Abbott antigen immunoassay, which measures predominantly p17 and p24 core antigens and has a sensitivity of $30 \mathrm{pg} / \mathrm{ml}$. HIV antigenaemia correlates poorly with the presence of plasma viraemia, however, and the absence of core antigens does not exclude the presence of infectious virus. ${ }^{19}$ The infectious dose of HIV for man is not known and the presence of integrated HIV DNA on a bronchoscope recently removed from a patient with AIDS implies that the potential for cross infection exists.

Cleaning in detergent proved effective in removing all detectable contamination from bronchoscopes. Of particular note was the removal of all detectable HIV. The bacterial reductions achieved with cleaning compared favourably with the generally accepted criterion for disinfectant efficacy-that is, a 4 log unit reduction in contaminating organisms. HIV has been found to retain its infectivity at room temperature even when dried ${ }^{2021}$ and is more resistant to glutaraldehyde in the presence of protein. Precleaning is therefore essential after every bronchoscopy procedure and should not be delayed until after disinfection, as has been advocated. ${ }^{22}$

We wish to thank the Department of Health, Medical Research Council, Keymed, Surgikos, and the Sanatorium Society for founcil, Keymed

1 Credle W, Smiddy J, Elliott RC. Complications of fiberoptic bronchoscopy. Am Rev: Respir Dis 1974;109:67-72.

2 Nelson KE, Larson PA, Schraufnagel DE, Jackson J.

Transmission of tuberculosis by flexible fibrebroncho- scopes. Am Rev Respir Dis 1983;127:97-100.

3 Leers W. Disinfecting endoscopes: how not to transmit Mycobacterium tuberculosis by bronchoscopy. Can Med Ass J 1980;123:275-80.

4 Pappas SA, SchaaffDM, Diconstanzo MB, King FW, Sharp JT. Contamination of flexible fibreoptic bronchoscopes. Am Rev Respir Dis 1983;127:391-2.

5 Webb SF, Vall-Spinosa A. Outbreak of Serratia marcescens associated with the flexible fibrebronchoscope. Chest 1975; 68:703-8.

6 Sammartino MT, Israel RH, Magnussen CR. Pseudomonas aeruginosa contamination of fibreoptic bronchoscopes. $J$ Hosp Infect 1982;3:65-71.

7 Goldstein B, Abrutyn E. Pseudo-outbreak of Bacillus species: related to fibreoptic bronchoscopy. $J$ Hosp Infect 1985;6:194-200.

8 Weinstein HJ, Bone RC, Ruth WE. Contamination of a fiberoptic bronchoscope with a Proteus species. Am Rev Respir Dis 1977;116:541-3.

9 Hussain SA. Fibreoptic bronchoscope related outbreak of infection with pseudomonas. Chest 1978;74:483.

10 Dawson DJ, Armstrong JG, Blacklock ZM. Mycobacterial cross contamination of bronchoscopy specimens. Am Rev Respir Dis 1982;126:1095-7.

11 Birnie GG, Quigley EM, Clements GB, Follet EAC, Walkinson $G$. Endoscopic transmission of hepatitis B virus. Gut 1983;24:171-4.

12 Saiki R, Gelfand DH, Stoffel S, et al. Primer-directed enzymatic amplification of DNA with a thermostable DNA polymerase. Nature 1988;239:487-91.

13 Hanson PJV, Gor D, Clarke JR, et al. Contamination of fibreoptic endoscopes in AIDS. Lancet 1989;ii:86-8.

14 Ayliffe GAJ, Babb JR, Bradley CR. The immersible endoscope. Lancet $1984 ; \mathrm{i}: 161$.

15 Lo Y-MD, Mehal WZ, Fleming KA. False-positive results and the polymerase chain reaction. Lancet 1988;ii:679.

16 Salahuddin SZ, Rose RM, Groopman JE, Markham PD, Gallo RC. Human T lymphotropic virus type III infection of human alveolar macrophages. Blood 1986;68:281-4.

17 Resnick L, Pitchenik AE, Fisher E, Croney R. Detection of HTLVIII/LAV specific IgG and antigen in bronchoalveolar lavage fluid from two patients with lymphocytic interstitial pneumonitis associated with AIDS-related complex. Am J Med 1987;82:553-6.

18 Chayt KJ, Harper ME, Marselle LM, et al. Detection of HTLV III RNA in lungs of patients with AIDS and pulmonary involvement. JAMA 1986;256:2356-9.

19 Coombs RW, Collier AC, Allain JP, Nikora B, Leuther M, Gjerset GF, Corey L. Plasma viremia in human immunodeficiency virus infection. N Engl J Med 1989; 321:1626-31

20 Hanson PJV, Gor D, Jeffries DJ, Collins JV. Chemical inactivation of HIV on surfaces. BMJ 1989;298:862-4.

21 Resnick L, Veren K, Salahuddin SZ, 'Tondreau S, Markham PD. Stability and inactivation of HTLVIIII/LAV under clinical and laboratory environments. JAMA 1986; 255:1887-91

22 Department of Health and Social Security. Guidance for surgeons, anaesthetists, dentists and their teams in dealing with patients infected with HTLV III. London: DHSS, 1986. (AIDS booklet 3 .) 